\title{
PENETRATION RESISTANCE AND DENSITY OF A YELLOW OXISSOL UNDER CONVENTIONAL MANAGEMENT AT DIFFERENT AGES
}

\author{
RESISTENNCIA A PENETRAÇÃO E DENSIDADE DE UM LATOSSOLO AMARELO \\ SOB MANEJO CONVENCIONAL EM DIFERENTES IDADES
}

\section{Leovanio Rodrigues BARBOSA ${ }^{1}$; Luís Alfredo Pinheiro Leal NUNES ${ }^{2}$; Ademir Sérgio Ferreira de ARAÚJO²; Francisco Rafael da SILVA ${ }^{3}$; Thiago Vinícius Barros IBIAPINA ${ }^{4}$}

\begin{abstract}
1. Doutorando do Programa de Pós-Graduação em Ciência do Solo, Universidade Federal do Paraná-UFPR, Curitiba; leovaniobarbosa@ hotmail.com; 2. Professor Associado I, Universidade Federal do Piauí, Teresina, PI, Brasil; 3. Estudante de Agronomia, bolsista de Iniciação Científica, Universidade Federal do Piauí, Teresina; 4. Doutor, Bolsista PNPD, Universidade Federal do Piauí, Teresina, PI, Brasil.
\end{abstract}

\begin{abstract}
RESUMO: Brazilian agriculture has been highlighted in Savanna areas due to significant gains in production and productivity in this biome. However, the production model with intensive use of machines for several years causes drastic changes in soil physical quality. This study aimed to investigate the influence of conventional management adoption time in a Yellow Oxissol on soil physical properties. Soil density, particle density, total porosity and soil resistance to penetration were assessed in areas under conventional management, in different usage times, in comparison to a native Savanna, which was used as control. The areas under conventional management contributed to increase the density and reduce the porosity, which was intensified with time of soil use. In the 6 years area, the porosity showed values below $0.50 \mathrm{~m}^{3} \mathrm{~m}^{-3}$ in the two measured layers. Higher penetration resistance values were observed to areas with higher use of time from $0.15 \mathrm{~m}$ depth, reaching values above 3.0 and $2.0 \mathrm{MPa}$ in soils with 6 and 3 years of use, respectively, which is ranked as high. The native vegetation and the newly deforested area have provided less resistance to penetration along the profile, with values falling into low and moderate classes. Different time periods since the implementation of soil management were differentiated by the physical properties of studied soils.
\end{abstract}

KEYWORDS: Physical attributes. Soil compaction. Savanna.

\section{INTRODUCTION}

The Piauí Native Savanna, which is considered by many as the last agricultural frontier in Brazil, has an area of 8.5 million hectares accounting for about $30 \%$ of the total area of the Brazilian northern Native Savanna (AGUIAR; MONTEIRO, 2005). Due to its favorable environmental conditions (latitude, altitude, rainfall, topography and soil), this area has been highlighted on the national scene as a high-potential region for the production of grains, such as corn, rice, and especially the soybean crop.

Native Savanna soils are predominantly of Oxissol classes, and are characterized by high acidity, low base saturation and high aluminum saturation. On the other hand, these are soils that show favorable physical conditions for agriculture, since they are flat, deep and well-drained, which means that rational fertilization makes them potentially suitable for agricultural production (KER, 1999).

However, cultures implementation in this region is usually done through conventional management with intensive heavy machinery use, from soil preparation to final product harvest, what causes changes in the physical attributes. Recent studies show that the high pressures from machines contact exceeding the load bearing capacity of the soil, in successive cropping, promote physical attributes changes in Native Savanna soils. This is because conventional management breaks macroaggregates and accelerates organic matter decomposition with time (IBIAPINA et al. 2014; SILVA, SILVA; FERREIRA, 2005), what is reflected in the soil density (ARATANI et al., 2009; PRAGANA et al., 2012) and soil penetration resistance (DRESCHER et al., 2012), affecting the retention capacity and water infiltration (LOSS et al., 2009).

Changes in density and soil porosity can vary considerably, depending on the texture, soil organic matter and soil cultivation frequency (HAJABBASI; JALALIAN; KARIMZADEH 1997). For Letey (1985), soil physical quality for plant growth is determined not only by good porosity, which provides water and oxygen, but also by the resistance that the soil matrix offers to roots penetration. Thus, in a degraded soil, besides reducing available water amount, oxygen diffusion rate and soil penetration resistance may limit plant 
growth, affecting its productivity (DRESCHER et al., 2012).

Given the above, this study aimed to evaluate the soil properties in areas with different crop years under conventional management, through assessment of the values of its physical quality indicators compared to a native Savanna forest.

\section{MATERIAL AND METHODS}

The study was conducted on the Real farm located at Regeneração City, Piauí, State, Brazil, with an altitude of $450 \mathrm{~m}$, geographical coordinates $\left(06^{\circ} 14^{\prime} 16^{\prime \prime}\right.$ South latitude and 42 $41^{\prime} 18^{\prime \prime}$ West longitude). The soil, according to Piauí state soil exploratory recognition survey, is a Yellow Oxissol. The region has an average annual temperature of 32 ${ }^{\circ} \mathrm{C}$ and average annual rainfall of $1350 \mathrm{~mm}$, with rainfall distributed from January to May (Equatorial Continental Scheme, with annual isohyets between 800-1400 mm). The climate, according to Köppen climate classification, is of (Aw') type.

Four managed areas with similar morphopedological characteristics have been chosen, namely: 1) First year of rice cultivation (PC1). The conventional management was used from planting to harvest, using plow and grade. Liming with dolomite lime and NPK fertilization were performed according to the needs required by soil analysis; 2) area in the third year of cultivation (PC3), where there were soybean/corn/soybean successive crops. Fertilization, liming and soil management were identical to $\mathrm{PC} 1$; 3) area in the sixth year of cultivation (PC6), with 1 year of rice cultivation and five years of soybean cultivation. Fertilization and soil management were identical to PC1; 4) Native Sananna Forest used as a reference, because it is a system in equilibrium and with no history of human intervention.

In each area, four plots of georeferenced $200 \mathrm{~m}^{2}$ were marked. In each plot, a volumetric core undisturbed soil samples were collected to determine soil density (SD). The particle density (PD) was determined by the volumetric flask method. The total porosity (TP) was calculated by the equation: $\mathrm{TP}=(1-\mathrm{SD} / \mathrm{PD}) \mathrm{x} 100$. Soil texture was determined by total dispersion granulometric analysis, and the results are in Table 2.

Table 2. Soils granulometric composition in the studied management systems.

\begin{tabular}{cccccc}
\hline \multirow{2}{*}{ System } & \multicolumn{4}{c}{ Granulometry $\left(\mathbf{g ~ k g}^{\mathbf{- 1}}\right)$} & \multirow{2}{*}{ Texture class } \\
\cline { 2 - 4 } & Coarse sand & Fine sand & Silt & Clay & \\
\hline PC1 & 120 & \multicolumn{5}{c}{ Depth $(0.00-0.20 \mathrm{~m})$} \\
PC3 & 125 & 190 & 200 & 420 & Very clayey \\
PC6 & 142 & 200 & 240 & 418 & Very clayey \\
MN & 160 & 270 & 210 & 360 & Very clayey \\
\hline \multicolumn{5}{c}{ Depth $(0.20-0.40 \mathrm{~m})$} \\
\hline PC1 & 125 & 260 & 185 & 430 & Very clayey \\
PC3 & 120 & 214 & 206 & 460 & Very clayey \\
PC6 & 150 & 192 & 208 & 450 & Very clayey \\
MN & 138 & 230 & 170 & 462 & Very clayey \\
\hline
\end{tabular}

PC1: Area with a year of conventional tillage; PC3: area with three years of conventional tillage; PC6: area with six years of conventional tillage; MN: native Savanna .forest

The resistance to penetration in soil was perfomed with gravimetric humidity ranging from 21 to $23 \%$ until the layer of $0.40 \mathrm{~m}$ (Table 3), using the impact penetrometer, IAA/Planalsucar - Stolf model, through the penetration of a shank into the soil and from the impact of a weight in free fall at a height of $0.4 \mathrm{~m}$. The following expression was used: $R(M P a)=(5.6+6.89 . N) \cdot 0.0980665$

Where:

$\mathrm{R}$ - Soil penetration resistance in MPa
$\mathrm{N}$ - Number of impacts per penetration decimeter

Resistance values were calculated from 0.05 $\mathrm{m}$ depth. From obtained values, layers were described with respect to its compaction degree, according to USDA (1993), which considers the 2 $\mathrm{MPa}$ limit as root growth strong restriction.

Data were subjected to analysis of variance and the means were compared by Tukey test at 5\% probability, using the ASSISTAT computer system, 7.7 beta version. 
Tabela 3. Gravimetric humidity of the Yelow Oxissol under different cropping systems.

\begin{tabular}{lllll}
\hline Layer $(\mathrm{m})$ & PC1 & PC3 & PC6 & MN \\
\cline { 2 - 5 } & \multicolumn{5}{c}{$\%$} \\
\hline $0-0,20$ & 24,75 & 24,89 & 24,42 & 24,50 \\
$0,20-0,40$ & 22,35 & 21,07 & 20,15 & 22,80 \\
Média & 23,55 & 22,98 & 22,28 & 23,65 \\
\hline
\end{tabular}

PC1: Area with a year of conventional tillage; PC3: area with three years of conventional tillage; PC6: area with six years of conventional tillage; $\mathrm{MN}$ : native Savanna forest.

\section{RESULTS AND DISCUSSION}

The loss of total organic carbon as a result of management practices involving annual crops with intensive soil disturbance, through plowing and harrowing, can be identified only years after these periodic use (POWLSON; BROOKES, 1987) as can be observed by the lower levels presented by the annual crop in PC6 area, compared to the others (Table 4). For Campos et al. (1995), in management systems of conventional planting the crop residues are placed in closer contact with the ground, besides favoring the rupture of aggregates, exposing protected fractions of organic matter

Table 4. Total organic carbon of the Yellow Oxisol under different cropping systems.

\begin{tabular}{|l|l|l|c|c|}
\hline \multirow{2}{*}{ Layer (m) } & PC1 & PC3 & PC6 & MN \\
\cline { 2 - 5 } & \multicolumn{3}{|c|}{$\mathrm{g} \mathrm{Kg}^{-1}$} \\
\hline $0-0.20$ & $9.29 \mathrm{~b}$ & $9.09 \mathrm{~b}$ & $7.74 \mathrm{c}$ & $10.53 \mathrm{a}$ \\
\hline $0.20-0.40$ & $8.69 \mathrm{ab}$ & $9.17 \mathrm{a}$ & $7.26 \mathrm{c}$ & $8.20 \mathrm{~b}$ \\
\hline
\end{tabular}

PC1: Area with a year of conventional tillage; PC3: area with three years of conventional tillage; PC6: area with six years of conventional tillage; MN: native Savanna forest.

Soil density average values (SD) in different management systems and evaluation periods are shown in Table 5. There was a significant interaction effect between studied management systems studied $(\mathrm{p}<0.05)$. In the PC3 and PC6, up to $0.20 \mathrm{~m}$, and PC6, up to $0.40 \mathrm{~m}$ management systems, significant SD changes occurred related to
Savanna vegetation soil. The extremes were observed in forest soil, being less dense $\left(0.93 \mathrm{~kg} \mathrm{~m}^{-}\right.$ ${ }^{3}$ ) in the layer up to $0.20 \mathrm{~m}$, and in the PC6 system, which showed a soil density value of $\left(1,29 \mathrm{~kg} \mathrm{~m}^{-3}\right)$, which was higher than the other environments, in the layer up to $0.20 \mathrm{~m}$, similar to the results observed by Bono et al., (2013).

Table 5. Soil density (SD), particle density (PD) and total porosity (TP) at two depths of a Yellow Oxissol, in the studied management systems

\begin{tabular}{|c|c|c|c|}
\hline \multirow{3}{*}{ Treatments } & SD & PD & $\mathbf{T P}$ \\
\hline & \multicolumn{2}{|c|}{$\mathrm{Kg} \mathrm{m}^{-3}$} & $\mathrm{~m}^{3} \mathrm{~m}^{-3}$ \\
\hline & \multicolumn{3}{|c|}{$\operatorname{Depth}(0.00-0.20 \mathrm{~m})$} \\
\hline $\mathrm{PC} 1$ & $0.96 \mathrm{bc}$ & $2.23 \mathrm{a}$ & $0.56 \mathrm{ab}$ \\
\hline PC3 & $1.03 \mathrm{~b}$ & $2.24 \mathrm{a}$ & $0.53 \mathrm{~b}$ \\
\hline PC6 & $1.19 \mathrm{a}$ & $2.26 \mathrm{a}$ & $0.47 \mathrm{c}$ \\
\hline $\mathrm{MN}$ & $0.93 \mathrm{c}$ & $2.20 \mathrm{a}$ & $0.57 \mathrm{a}$ \\
\hline \multirow[t]{2}{*}{$\mathrm{CV} \%$} & 4.98 & 4.20 & 4.83 \\
\hline & \multicolumn{3}{|c|}{ Depth $(0.20-0.40 \mathrm{~m})$} \\
\hline $\mathrm{PC} 1$ & $1.03 \mathrm{~b}$ & $2.22 \mathrm{a}$ & $0.53 \mathrm{a}$ \\
\hline PC3 & $1.08 \mathrm{~b}$ & $2.24 \mathrm{a}$ & $0.51 \mathrm{a}$ \\
\hline PC6 & $1.29 \mathrm{a}$ & $2.24 \mathrm{a}$ & $0.42 \mathrm{~b}$ \\
\hline $\mathrm{MN}$ & $1.04 \mathrm{~b}$ & $2.22 \mathrm{a}$ & $0.53 \mathrm{a}$ \\
\hline $\mathrm{CV} \%$ & 6.51 & 4.44 & 7.42 \\
\hline
\end{tabular}

PC1: Area with a year of conventional tillage; PC3: area with three years of conventional tillage; PC6: area with six years of conventional tillage; MN: native Savanna forest. Mean followed by the same letter were not statistically different by $t$ test at $5 \%$ probability. 
In soils with heavy agricultural management, it is expected to soil density to be higher than in less managed or without human intervention areas, and this occurs by the fact that, in these areas, traffic machines use causes changes in soil structure over time, resulting in compaction, in addition to organic matter decline. In this study, the lower SD values were observed in freshly upturned native Savanna soil. Fontenele et al. (2009), while studying a Yellow Oxissol physical attributes under management systems in Piauí Savanna, also found higher density values in prolonged conventional tillage in relation to native Savanna or newly deforested areas. Similar results were also observed by Torres, Fabian and Pereira (2011) in Native Savanna Oxissol with heavy machine traffic. The authors found high density levels in depths from 0.10 to $0.20 \mathrm{~m}$, and attributed the fact to machine traffic pressure during several years of cultivation.

In depth from 0.20 to $0.40 \mathrm{~m}$, there was no statistical difference in soil density between native forest and PC1 and PC3 systems. However, in the PC6 system, which had longer agricultural holding, SD increased in about $26 \%$ compared to native Savanna. Beutler et al. (2007) found soybean yield decrease under rainfed and irrigated farming, from the soil density of 1.26 and $1.29 \mathrm{Mg} \mathrm{m}-3$, respectively, in a study conducted in a very clayey Red Oxissol.

In contrast, the soil under native forest had the lowest density in the two analyzed depths. It is known that the Savanna is a tropical forest in which a low vegetation, which composed mainly of grasses that coexist with trees and sparse shrubs, contribute with a large amount and variety of residues in the soil. This favors microorganisms interactions with the amount of material that they will contribute to aggregates formation, and consequently to soil density loss (TISDALL; OADES, 1982). In addition, the absence of soil management with machine use prevents macroaggregates disruption, preserving organic matter, according to studies in Oxissol areas (ANDRADE et al., 2009; VIANA et al., 2011).

Particle density (PD) in cultivated areas (PC1, PC3 and PC6) and in the native forest, both for the depth from 0.00 to $0.10 \mathrm{~m}$ and for 0.10 to $0.20 \mathrm{~m}$, showed no statistical difference (Table 3). Studying the physical and hydraulic properties in a Native Savanna Oxissol under different management systems, Figueiredo et al. (2009) also found similar results. According to Brady (1989), these results are expected because particle density is dependent on the predominant nature of the soil source material, and thus, little or no difference for the same soil class is shown.

The total porosity (TP) was higher in the $0.57 \mathrm{~m}^{3} \mathrm{~m}^{-3}$ native forest and the PC6 area had the lowest value, $0.47 \mathrm{~m}^{3} \mathrm{~m}^{-3}$, in the $0.00-0.10 \mathrm{~m}$ layer, while the $0.10-0.20 \mathrm{~m}$ layer, in the PC6 area, had a lower value $\left(0.47 \mathrm{~m}^{3} \mathrm{~m}^{-3}\right)$, and the native forest and the PC1 and PC6 areas had higher values and were not statistically different from each other (Table 3). Thus, in comparison with forest porosity, there were average reductions of $18 \%$ and $21 \%$ in 0 to 0.10 and $0-0.20 \mathrm{~m}$ layers, respectively, in the PC6 area with longer use period.

Several studies show that agricultural machinery heavy traffic and agricultural implements used in conventional management system lead to soil compaction and cause interference in soil structure with time, promoting porosity reduction, especially in deeper layers (BONO et al. 2014; CARNEIRO et al., 2009; FIGUEIREDO et al., 2009). Stone et al. (1994), after seven successive crops of rice and beans in a Savanna Oxissol, found reduction in total porosity, saturated hydraulic conductivity and available water, in addition to increase in soil density and water retention at a given matric potential, in the layers of $0-0.20$ and 0.20-0.40 m soil depth.

It is likely that SD increase and TP reduction over time in crops areas are also related to rain drops impact on the soil surface, facilitating particles disaggregation and removal due to the lack of vegetation during the off-season. In the forest, the biomass, besides causing a higher OM accumulation, also influences soil physical properties, as it acts as an insulator to prevent or reduce raindrops direct action, contributing to create a more favorable environment to its aggregation (CAMPOS et al., 1995). Furthermore, as not suffering machinery and equipment transit, the area under native forest showed lower density and higher total porosity values compared to cultivated soils, corroborating to Andrade et al. (2009) and Godoy et al. (2013) results.

Soil resistance to penetration (SRP) is one of the most used physical attributes as an indicator of soil compaction (BEAUTLER; CENTURION, 2004). In Figure 2, soil resistance to penetration values (SRP) show that management systems, which were submitted to the agricultural areas, are different. There was a sharp increase in the SRP value after the $0.15 \mathrm{~m}$ layer depth to PC3 and PC6 systems. 


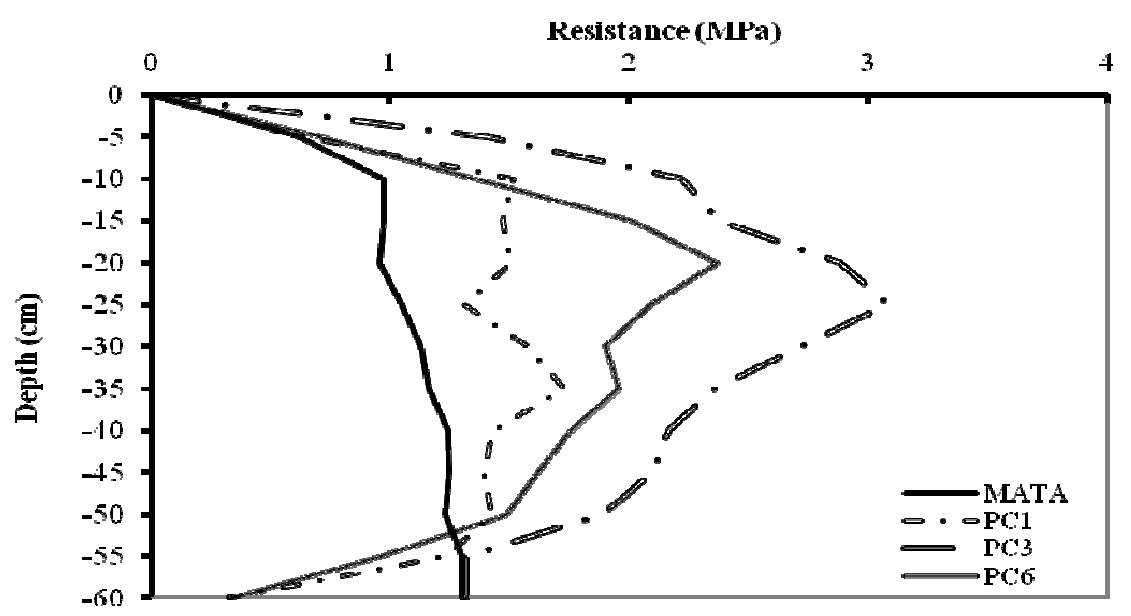

Figure 2. Soil resistance to vertical penetration in a yellow Oxissol in the studied cropping systems.

The values found were above the $2.0 \mathrm{MPa}$ limit value, considered by the USDA (1993) as restrictive to roots development (Table 4). This aspect is related to conventional management system, as operations with heavy farm machinery held with relative intensity, from soil preparation to harvest in areas of annual crops, provide the formation of a more compacted layer due to pressures, as well as plow action, which normally goes until this depth (BEUTLER et al., 2001). On the other hand, the MN and PC1 systems showed a small increase in SRP in the lower class during the studied profile, although lower than 2.0 MPa.

Table 4. Soil penetration resistance classes.

\begin{tabular}{cc}
\hline Class & Resistance to penetration (MPa) \\
\hline Extremelly low & $<0.01$ \\
Very low & $0.01-0.1$ \\
Low & $0.1-1.0$ \\
Moderated & $1.0-2.0$ \\
High & $2.0-4.0$ \\
Very high & $4.0-8.0$ \\
Extremely high & $>8.0$ \\
\hline USDA (1993) &
\end{tabular}

In some researches, it has been observed that in soil conventional management SRP is high, especially over long periods of soil use. Studies by Torres et al., (2011) in a Oxissol submitted to different management systems showed that, in a preserved area, SRP values were of less than $2 \mathrm{MPa}$, while in areas with agricultural use, the value was higher (4.8 MPa), reflecting on a high SRP.

Beutler et al. (2001) found high vertical penetration resistance values to the system with conventional tillage, with disk plow and rotation cultivation with corn and beans at a depth of 15-30 $\mathrm{cm}$ in the soil, and a $3.04 \mathrm{MPa}$ value, which is rated high and may be an indicative of root development and soil compaction restriction. The authors attributed these high values to machinery traffic and disk plow action being always at the same depth, beyond the experiment conduction time.

For Beutler et al. (2007), excessive soil compaction caused soybean yield decrease from soil penetration resistance of 1.30 and $1.64 \mathrm{MPa}$, in rainfed and irrigated farming in a very clayey dystrophic Red Oxissol. Other research found that the maximum soybean yield was associated with SRP of 1.57 to $1.59 \mathrm{MPa}$ up to the $0.35 \mathrm{~m}$ (VASQUEZ et al. 1989) and 1.80 MPa layer in a clayey Oxissol (SILVA et al., 2000). However, according to Beutler and Centurion (2004) and Rossetti et al., (2012), soybean yield decreases with SRP higher than $0.85 \mathrm{MPa}$, which are also lower values than those found in soy SRP in this study.

\section{CONCLUSIONS}

The highest penetration resistance values were observed on systems in which plows and harrows were used for a long time

Different periods of time since the implementation of soil management were differentiated by soil density and porosity. 
Studied variables were effective as indicators of soil physical quality.

\section{ACKNOWLEDGMENT}

The authors thank the Higher Education Personnel Training Coordination (CAPES), for the financial and logistical aid.

RESUMO: A agricultura brasileira vem se destacando em áreas sob Cerrado devido aos ganhos significativos na produção e produtividade nesse bioma. No entanto, o modelo de produção com uso intensivo de máquinas por vários anos provoca alterações drásticas na qualidade física do solo. Neste trabalho, objetivou-se investigar o impacto do manejo convencional constante sobre os atributos físicos do solo. Foram avaliadas a densidade do solo, densidade de partículas, porosidade total e resistência do solo à penetração, em áreas sob manejo convencional em diferentes tempos de uso em relação a uma mata nativa de cerrado que foi usada como controle. As áreas sob manejo convencional contribuiu para aumentar a densidade e diminuir a porosidade que se intensificou com o tempo de uso do solo. Na área com 6 anos, a porosidade mostrou valores abaixo de $0,50 \mathrm{~m}^{3} \mathrm{~m}^{-3}$ nas duas camadas avaliadas. Observaram-se maiores valores de resistência à penetração para as áreas com maior tempo de uso a partir da profundidade $0,15 \mathrm{~m}$, alcançando valores superiores a 3,0 e 2,0 MPa, nos solos com 6 e 3 anos de uso, respectivamente, classificado como alto. O cerrado nativo e a área recém-desmatada propiciaram menor resistência à penetração ao longo do perfil com valores classificados nas classes baixa e moderada. Períodos de tempo distintos desde a aplicação de manejos de solo foram diferenciados pelos atributos físicos do solo estudados.

PALAVRAS CHAVES: Atributos físicos. Compactação do solo. Cerrado.

\section{REFERENCES}

AGUIAR, T. J. A.; MONTEIRO, M. S. L. Modelo agrícola e desenvolvimento sustentável: a ocupação do cerrado piauiense. Ambiente \& Sociedade, Campinas, v. 8, n. 01, p. 161-178, 2005.

http://dx.doi.org/10.1590/S1414-753X2005000200009

ANDRADE, R. S.; STONE, L. F.; SILVEIRA, P. M. Culturas de cobertura e qualidade físicas de um Latossolo em plantio direto. Revista Brasileira de Engenharia Agrícola e Ambiental, Campina Grande, v. 13, n. 4, p. 411-418, 2009. http://dx.doi.org/10.1590/S1415-43662009000400007

ARATANI, R. G.; FREDDI, O. S.; CENTURION, J. F.; ANDRIOLI, I. Qualidade física de um Latossolo Vermelho acriférrico sob diferentes sistemas de uso e manejo. Revista Brasileira Ciência Solo, Viçosa, v. 33, n. 3, p. 677-687, 2009.

BEUTLER, A. N.; CENTURION, J. F.; CENTURION, M. A. P. C.; LEONEL, C. L.; SÃO JOÃO, A. C. G.; FREDDI, O. S. Intervalo hídrico ótimo no monitoramento da compactação e da qualidade física de um Latossolo Vermelho cultivado com soja. Revista Brasileira de Ciência do Solo, Viçosa, v. 31, n. 6, p. 1223$1232,2007$.

BEUTLER, A. N.; CENTURION, J. F. Compactação do solo no desenvolvimento radicular e na produtividade da soja. Pesquisa Agropecuária Brasileira, Brasília, v. 39, n. 6, p. 581-588, 2004.

http://dx.doi.org/10.1590/S0100-204X2004000600010

BEUTLER, A. N.; SILVA, M. L. N.; CURI, N.; FERREIRA, M. M.; CRUZ, J. C.; PEREIRA FILHO, I. A. Resistência à penetração e permeabilidade de Latossolo Vermelho distrófico típico sob sistemas de manejo na região dos cerrados. Revista Brasileira de Ciência do Solo, Viçosa, v. 25, n. 1, p. 167-177, 2001.

BONO, J. A. M.; MACEDO, M. C. M.; TORMENA, C. A. Qualidade física do solo em um Latossolo vermelho da região sudoeste dos cerrados sob diferentes sistemas de uso e manejo. Revista Brasileira Ciência Solo, Viçosa, v. 37, n. 3, p. 743-753, 2013.

BRADY, N. C. Natureza e propriedades dos solos. 7. ed. Rio de Janeiro: Freitas Bastos. 1989. 878p. 
CAMPOS, B. C.; REINERT, D. J.; NICOLODI, R.; RUEDELL, J.; PETRERE, C. Estabilidade estrutural de um Latossolo Vermelho-Escuro distrófico após sete anos de rotação de culturas e sistemas de manejo de solo. Revista Brasileira de Ciência do Solo, Viçosa, v. 19, n. 1, p. 121-126, 1995.

CARNEIRO, M. A. C.; SOUZA, E. D.; REIS, E. F.; PEREIRA, H. S.; AZEVEDO, W. R. Atributos Físicos, Químicos e Biológicos de Solo de Cerrado sob Diferentes Sistemas de uso e Manejo. Revista Brasileira de Ciência do Solo, Viçosa, v. 33, n. 1, p. 147-157, 2009.

DRESCHER, M. S.; ELTZ, F. L. F.; DENARDIN, J. E.; FAGANELLO, A.; DRESCHER, G. L. Resistência à penetração e rendimento da soja após intervenção mecânica em Latossolo Vermelho sob plantio direto. Revista Brasileira de Ciência do Solo, Viçosa, v. 36, n. 6, p. 1836-1844, 2012.

FIGUEIREDO, C. C.; SANTOS, G. C.; PEREIRA, S. NASCIMENTO, J. L.; JÚNIOR, J. A. Propriedades físico-hídricas em Latossolo do Cerrado sob diferentes sistemas de manejo. Revista Brasileira de Engenharia Agrícola e Ambiental, Campina Grande, v. 13, n. 2, p. 146-151, 2009. http://dx.doi.org/10.1590/S141543662009000200006

FONTENELE, W.; SALVIANO, A. A. C.; MOUSINHO, F. E. P. Atributos físicos de um Latossolo Amarelo sob sistemas de manejo no cerrado piauiense. Revista Ciência Agronômica, Fortaleza, v. 40, n. 2, p. 194-202, 2009.

GODOY, S. G.; STONE, L. F.; B. FERREIRA, E. P. B.; COBUCCI, T.; LACERDA, M. C. Atributos físicos, químicos e biológicos do solo impactado por cultivos sucessivos de arroz. Revista Brasileira de Engenharia Agrícola e Ambiental, Campina Grande, v. 17, n. 2, p. 1278-1285, 2013. http://dx.doi.org/10.1590/S141543662013001200005

HAJABBASI, M. A.; JALALIAN, A. ; KARIMZADEH, H. R. Deforestation effects on soil physical and chemical properties. Plant Soil, The Hague, v. 190, p. 301-308, 1997.

http://dx.doi.org/10.1023/A:1004243702208

IBIAPINA, T. V. B.; SALVIANO, A. A. C.; NUNES, L. A. P. L. ; MOUSINHO, F. E. P.; LIMA, M. G.; SOARES, L. M. S. Resistência à penetração e agregação de Latossolo Amarelo sob monocultivo de soja e de eucalipto no cerrado piauiense. Cientifica, Jaboticabal, v. 42, n. 4, p. 411-418, 2014.

KER, J. C. Latossolos do Brasil: uma revisão. Geonomos, Belo Horizonte, v. 5, n. 1, p. 17-40, 1999.

LETEY, J. Relationship between soil physical properties and crop production. Advances in Soil Science, New York, v. 1, n. 2, p. 277-294. 1985.

LOSS, A.; PEREIRA, M. G.; SCHULTZ, N.; ANJOS, L. H. C.; SILVA, E. M. R. Atributos químicos e físicos de um Argissolo Vermelho-Amarelo em sistema integrado de produção agroecológica. Pesquisa Agropecuária Brasileira, Brasília, v. 44, n. 1, p. 68-75, 2009. http://dx.doi.org/10.1590/S0100-204X2009000100010

POWLSON, D. S.; BROOKES, P. C. K.; CHRISTENSEN, B. T., Measurement of soil microbial biomass provides an early indication of changes in total organic matter due to straw incorporation. Soil Biology Biochemistry, Oxford, v. 19, p. 159-164, 1987. http://dx.doi.org/10.1016/0038-0717(87)90076-9

PRAGANA, R. B.; RIBEIRO, M. R.; NÓBREGA, J. C. A; RIBEIRO FILHO, M. R.; COSTA, J. A. Qualidade física de latossolos amarelos sob plantio direto na região do cerrado piauiense. Revista Brasileira de Ciência do Solo, Viçosa, v. 36, n. 5, p. 1591-1600, 2012.

ROSSETTI, K. V.; CENTURION, J. F.; SOUSA NETO, E. L. Physical quality of an Oxisol after different periods of management systems. Revista Brasileira de Ciência do Solo, Viçosa, v. 37, n. 6, p. 1522-1534, 2013 
SILVA, R. R.; SILVA, M. L. N.; FERREIRA, M. M. Atributos físicos indicadores da qualidade do solo sob Sistemas de manejo na bacia do alto do Rio Grande. Ciência e Agrotecnologia, Lavras, v. 29, n. 4, p. 719-730, 2005.

SILVA, V. R.; REINERT, D. J.; REICHERT, J. M. Resistência mecânica do solo à penetração influenciada pelo tráfego de uma colhedora em dois sistemas de manejo do solo. Ciência Rural, Santa Maria, v. 30, n. 5, p. 795-801, 2000. http://dx.doi.org/10.1590/S0103-84782000000500009

STONE, L. F.; SILVEIRA, P. M.; ZIMMERMANN, F. J. P. Características físico-hídricas e químicas de um Latossolo após adubação e cultivos sucessivos de arroz e feijão, sob irrigação por aspersão. Revista Brasileira de Ciência do Solo, Viçosa, v. 18, n. 3, p. 533-539, 1994.

TISDALL, J. M.; OADES, J. M. Organic matter and water-stable aggregates in soils. Journal of Soil Science, London, v. 33, n. 1, p. 141-163, 1982. http://dx.doi.org/10.1111/j.1365-2389.1982.tb01755.x

TORRES, J. L. R.; FABIAN, A. J.; PEREIRA, M. G. Alterações dos atributos físicos de um Latossolo Vermelho submetido a diferentes sistemas de manejo. Ciência e Agrotécnologia, Lavras, v. 35, n. 3, p. 437445, 2011.

USDA, Soil survey manual. Washington: DC, USA, Soil Survey Division Staff, 1993. 437p.

VAZQUEZ, L.; MYHRE, D. L.; GALLAHER, R. N.; HANLON, E. A.; PORTIER, K. M. Soil compaction associated with tillage treatments for soybean. Soil Tillage Research, Oxford, v. 13, n. 1, p. 35-45, 1989. http://dx.doi.org/10.1016/0167-1987(89)90036-6

VIANA, E. T.; BATISTA, M. A.; TORMENA, C. A.; COSTA, A. C. S.; INOUE, T. T. Atributos físicos e carbono orgânico em Latossolo Vermelho sob diferentes sistemas de uso e manejo. Revista Brasileira de Ciência do Solo, Viçosa, v. 35, n. 6, p. 2105-2114, 2011. 